\title{
Yield Performances of Pleurotus ostreatus on Different Growth Substrates as Influence by Some Vegetable Additives
}

\author{
Markson,A. A, Agba, M.O, Akpan, J.B and Bassey, G.A \\ Department of Botany, University of Calabar, P. M. B. 1115. Calabar, Nigeria.
}

\begin{abstract}
This study was carried out to investigate the effects of some vegetables (Diplazium sammatii, Moringa oleifera, and Justicia insularis) as additives on the growth parameters of Pleurotus ostreatus cultivated on two substrates; banana leaves $(B L)$ and banana leaves/sawdust (BL/SD). The substrates were amended with these vegetables at different concentration levels $(0 \mathrm{~g}, 5 \mathrm{~g}, 10 \mathrm{~g}$ and $15 \mathrm{~g})$. Spawn running was completed in 30, 35, and 40 days in banana leaves, banana leaves/sawdust and the control respectively. Parameters assessed included area of pileus, number of fruit bodies, fresh weight, dry weight, length of stipe and girth of stipe. Higher mean values for fresh weight $(21.69 \mathrm{~g})$, area of pileus $\left(42.58 \mathrm{~cm}^{2}\right)$, length of stipe $(5.10 \mathrm{~g})$ and girth of stipe $(4.30 \mathrm{~g})$ were obtained from $\mathrm{BL}$ substrate treated to $5 \mathrm{~g} \mathrm{M}$. oleifera leaf powder. These values were significantly different from values obtained for other plant additives. Considering the number of fruit bodiesthat emerged on BL/SD substrates, the control produced more fruit bodies than the substrates with additives. The best performance in BL/SD substrates was observed when the substrate was treated to $10 \mathrm{~g} \mathrm{~J}$. insularis in some of the parameters assessed. These included fresh weight (20.64 g), number of fruit bodies (8.00) and stipe girth $(3.44 \mathrm{~cm})$. Other parameters like area of pileus $\left(36.08 \mathrm{~cm}^{2}\right)$ and dry weight $(2.39 \mathrm{~cm})$, control had a better performance. While for length of stipe, $15 \mathrm{~g} M$. oleifera leaf powder had the highest mean value that was significantly different $(P \leq 0.05)$ from what was observed in substrates amended with other additives. It is therefore evident that these vegetables have high potential for utilization as additives or supplements for growing of Pleurotus ostreatus especially when using BL as substrates. In addition, substratesadditive concentration combination played a significant role in selective organ growth of the test mushroom.
\end{abstract}

Keywords: Additives, amended, Pleurotus ostreatus, substrates, vegetables

\section{Introduction}

Pleurotus ostreatus is a common edible mushroom. It belongs to the family Pleurotaceae. In nature, it grows in tropical and temperate forests on decomposing materials such as dead trees or sometimes on tree trunks that are dying or woods of coniferous plants [1]. Cultivation of Pleurotus ostreatus first took place in Germany at subsistence level during the First World War but now it is cultivated at commercial level [2]. Species of mushroom in the genus Pleurotus are commonly referred to as oyster mushroom. However, to differentiate it from others, Pleurotus ostreatus is called tree oyster. Its mycelium is pure white in colour [2].Oyster mushrooms are among the first three mushrooms grown today globally. Its high nutritional and medicinal profile has encouraged widespread consumption [3]. This mushroom species contain abundance of amino acidsand is rich in proteins, minerals and vitamins [4].

The level of mushroom growth and development is greatly dependent on the environmental factors. One of such factors is the substrate of cultivation. Various substrates have already been identified as growth media for cultivating oyster mushroom. These include rice straw, coffee pulps, sawdust, and even paper. Most of these are of low-value lignocelluloses wastes that are primarily derived from agricultural products or the agro-industry [6].Many researchers in this field have grown several Pleurotus species using various substrate materials and achieved some level of success regarding their yield output $[7,8,9,10]$.The growth support potential of a substrate is a function of its nutritional content. Improvement of the nutrient profile of the growth substrate has been achieved through amendments with several materials. Such materials are called additives.

Additives could be organic or inorganic materials. The commonest organic materials used by many growers include, maize, wheat and rice, flours, cowpea, horse gram, poultry dung and cow dung $[14,15]$. Markson et al., 2012, reported the use of groundnut cake and palm kernel cake as additives in sawdust and banana leaves based substrate cultivation of $P$. ostreatus. Addition of $4 \%$ humic acid has been reported to record the best yield of $P$. ostreatus [16]. Also, the use of $30 \%$ oil cake and $30 \%$ tomato tuff produced satisfactory results in cultivation of $P$. ostreatus [11,12]. Maize straw was reported to be more suitable for cultivation of $P$. ostreatus when supplemented with cotton seed hull at an inclusion rate of $25 \%$ while $2 \%$ concentration of rice husk was also found to be the best in supporting the growth and yield of $P$. ostreatus [17]. Amendment of mushroom growth substrates with vegetables is not a common practice. However, there are several reports on the rich nutritional and phytochemical profiles of these vegetables [18, 19, 20 21] that are rarely given a place in the daily menu of the people. Yet, they are naturally growing and of cosmopolitan occurrence in our 
environment. In this study, growth substrates were amended with leaves Moringa oleifera (Lam), Diplazium sammatii(Kuhn) and Justicia insularis (T.Anders) to improve the productivity of the growth substrates (banana leaves and banana leaves/sawdust) for the cultivation of $P$. ostreatus.

\subsection{Location of study}

\section{Materials and methods}

The research was carried out at the University of Calabar staff quarters, University of Calabar, Cross River State lying within longitude $4^{\circ} 57^{\prime} 0^{\prime \prime}$ North and latitude $8^{\circ} 19^{\prime} 0 "$ "[22].

\subsection{Collection of materials}

The three plants used as additives were sourced within Cross Rivercentral (latitude 5.8 and longitude 8.08333 ) and south ( $4^{\circ} 57^{\prime} 0^{\prime \prime}$ North, $8^{\circ} 19^{\prime} 0^{\prime \prime}$ east). Diplazium sammatii (edible fern) and Justicia insularis were obtained from Ugep main market, Yakurr local area government of Cross River State, while Moringa oleifera was collected from the university of Calabar staff quarters, Cross River state, Nigeria. Materials for substrates composition (Dry banana leaves and sawdust) were obtained from the university of Calabar staff quarters and government owned timber market at Marian Road, Calabar, Cross River Staterespectively. The test mushroom was obtained from Royal farms at Ikot-Effanga, Calabar, Cross River State. Rice bran was sourced from a private owned rice mill in Ugep, Yakurr Local Government Area of Cross River State, while lime (gypsum) was purchased from Watt market in Calabar.

\subsection{Preparation of Plant Materials}

The plants were washed with clean water, sun dried and ground into fine powder.

\subsection{Composting of substrates}

Two substrate types (dry banana leaves and a mixture of dry banana leaves and sawdust) were composted for the cultivation. Fermented sawdust was collected from timber market and soaked for 24 hours. The banana leaves were shredded into bits of about $2 \mathrm{~cm}$ and soaked in water for 1 hour. These materials were transferred into sac bags and drained of water to a moisture level of about $70 \%$.About $7 \mathrm{~kg}$ of rice bran and 0.4 $\mathrm{kg}$ of lime were added to a hundred kilograms $(100 \mathrm{~kg})$ of banana leaves and properly mixed [5]. Fifty kilograms $(50 \mathrm{~kg})$ of sawdust was mixed with fifty kilograms $(50 \mathrm{~kg})$ of banana leaves, $4.75 \mathrm{~kg}$ of rice bran and $0.5 \mathrm{~kg}$ of lime. The substrate was then divided into $1.0 \mathrm{~kg}$ portions and dispensed into plastic bags measuring 30 $\mathrm{x} 11 \mathrm{~cm}$

\subsection{Pasteurization}

The plastic bags containing the substrates werepasteurized using metal drums of about 500litres capacity with a wooden platform of about $35 \mathrm{~cm}$ high at $60-80^{\circ} \mathrm{C}$ for 6 hours. Initial water level in the drums was $30 \mathrm{~cm}$ from the bottom of the drum. The pasteurized substrate was allowed to cool for 12 hours.

\subsection{Spawning}

Each of these portions was treated with $0 \mathrm{~g}$ (control), $5 \mathrm{~g}, 10 \mathrm{~g}$, and $15 \mathrm{~g}$ of powered leaf samples of Moringa oleifera leaves, Diplazium sammatii fronds and Justicia insularis leaves separately. The bags were inoculated with spawns of Pleurotus ostreatus. The open end of each bag was secured with PVC pipe of about $3 \mathrm{~cm}$ long and $3 \mathrm{~cm}$ in diameter wrapped with a rubber band and plugged with cotton wool [5]. Each experimental unit was replicated thrice.Spawn running was achieved by hanging the bags with ropes in sequence from the top of the roof down with each line having a maximum of eight bags. Limited amount of light was allowed into the spawn running unit.

\subsection{Experimental Design and Data Analysis.}

The experiment was laid out in complete randomized design (CRD) with three replications. Data collected were subjected to analysis of variance (ANOVA) using SPSS version 14.0 and means were separated using LSD.

\subsection{Cropping}

When spawn run was completed, that ismycelium had completely covered the bags, the bags were transferred to the cropping unit where they were stacked on shelves made of bamboo and opened to enable the mushrooms grow out. The opened mushroom bags werelightly sprayed with clean water daily. Coarse sand from the sea was poured on the floor of the cropping unit and was moistened continuously. The cropping unit was humidified to about 70-75 percent by wetting the walls of the mushroom house regularly. 
Yield Performances of Pleurotus Ostreatus on Different Growth Substrates as Influence by Some

\subsection{Harvesting}

Harvesting of mushrooms was at maturity (when the pileus were fully opened). The harvested mushrooms were thoroughly cleaned and data obtained for the following parameters; area of pileus, length of, girth of stipe, number of fruit bodies per bag, fresh weight and dry weight using `conventional methods.

\section{Results}

The different concentrations of the plant additives in the two substrates greatly influenced the mushroom growth. The performance of the mushroom depended upon the type additive concentration of the plant additives and the type of growth substrates. Banana leaves/sawdust (BLSD) substrate composite amended with all the levels of concentrations of $D$. sammatii and $15 \mathrm{~g}$ M. oleifera leaf powder did not support the growth of the test mushroom. Table 1shows the different growth parameters as influenced by the different concentrations of the plant additives in banana leaves (BL) substrates. Substrates treated to $5 \mathrm{~g}$ M. oleifera produced mushrooms with the largest pileus size of $42.58 \mathrm{~cm}^{2}$ which was significantly different $(\mathrm{P} \leq 0.05)$ from those produced by substrates treated to other plant additives. However, this performance was closely followed by the control experiment as well as BL treated to $10 \mathrm{~g} \mathrm{D}$. sammatii and $10 \mathrm{~g} \mathrm{~J}$. insularis. The least performing set-ups were all substrates amended with $5 \mathrm{~g} \mathrm{D}$. sammatii. The highest mean fresh weight $(21.69 \mathrm{~g})$ was exhibited by mushrooms grown on substrates treated to $5 \mathrm{~g} \mathrm{M}$. oleifera leaf powder which was significantly different $(\mathrm{P} \leq 0.05)$ from those produced by samples treated to other additive concentrations. D. sammatii leaf powder was at its best at $10 \mathrm{~g}$ concentration level but mushrooms fresh weight sustained by it was however not significantly different $(\mathrm{P} \leq 0.05)$ from those obtained for the control experiment. Amendments of BL substrates negatively contributed to the dry weight of the resulting mushrooms as the dry weight values from the control experiment were significantly $(\mathrm{P}<0.05)$ higher.

The highest mean stipe length $(5.1 \mathrm{~cm})$ was obtained from mushroom grown on banana leaves supplemented with $5 \mathrm{~g} \mathrm{M}$. oleifera and this was significantly higher $(\mathrm{P} \leq 0.05)$ than those produced on $\mathrm{BL}$ amended with other additives. With respect to stipe girth, BL substrate treated to $15 \mathrm{~g} \mathrm{D}$. sammatii produced mushroom with the biggest stipe diameter $(4.8 \mathrm{~cm})$ when compared to other additive concentrations. This was closely followed by BL treated to $5 \mathrm{~g} \mathrm{M}$. oleifera. With reference the number of fruit bodies produced, the control recorded better results than the treated samples in the BL substrates. However, BL substrates amended with $J$. insularis leaf powder recorded better results when compared with samples with other plant additives especially at $5 \mathrm{~g}$ and $10 \mathrm{~g}$ concentration levels.

Table 1: Effect of different concentration levels of additives on the growth parameters of Pleurotus ostreatus grown banana leaves substrates

\begin{tabular}{|c|c|c|c|c|c|c|}
\hline \multirow[t]{2}{*}{ Treatments } & \multicolumn{6}{|c|}{$\begin{array}{l}\text { Area of pileus }\left(\mathrm{cm}^{2}\right) / \text { Fresh and dry wt. }(\mathrm{g}) / \text { Length and girth of stipe }(\mathrm{cm}) / \mathrm{No} \text {. of fruit bodies } \\
\text { (count) }\end{array}$} \\
\hline & $\begin{array}{l}\text { Area of Pileus } \\
\left(\mathrm{cm}^{2}\right)\end{array}$ & $\begin{array}{l}\text { Fresh wt } \\
(\mathrm{g})\end{array}$ & Dry wt & $\begin{array}{l}\text { Length of } \\
\text { stipe }\end{array}$ & $\begin{array}{l}\text { Girth of } \\
\text { stipe }\end{array}$ & $\begin{array}{l}\text { No of fruit } \\
\text { bodies }\end{array}$ \\
\hline Control & 29.38 & 18.76 & 2.33 & 3.30 & 2.60 & 10.00 \\
\hline $5 \mathrm{~g} \quad$ Diplazium sammatii & 3.60 & 4.16 & 0.70 & 1.22 & 0.83 & 5.00 \\
\hline $10 \mathrm{~g} \quad$ Diplazium sammatii & 24.99 & 18.81 & 1.86 & 1.00 & 2.33 & 5.00 \\
\hline $15 \mathrm{~g} \quad$ Diplazium sammatii & 10.33 & 10.67 & 1.08 & 4.17 & 2.67 & 3.00 \\
\hline $5 \mathrm{~g} \quad$ Justicia insularis & 13.11 & 9.95 & 0.82 & 2.61 & 1.89 & 8.00 \\
\hline $10 \mathrm{~g}$ Justicia insularis & 23.48 & 13.84 & 1.37 & 2.83 & 2.17 & 7.00 \\
\hline $15 \mathrm{~g}$ Justicia insularis & 22.03 & 11.51 & 0.94 & 4.11 & 2.89 & 6.00 \\
\hline $5 \mathrm{~g} \quad$ Moringa oleifera & 42.58 & 21.69 & 2.11 & 5.11 & 4.30 & 5.00 \\
\hline $10 \mathrm{~g}$ Moringa oleifera & 16.56 & 12.91 & 1.22 & 3.70 & 2.78 & 6.00 \\
\hline $15 \mathrm{~g}$ Moringa oleifera & 0.00 & 0.00 & 0.00 & 0.00 & 0.00 & 0.00 \\
\hline LSD & 0.66 & 0.40 & 0.03 & 0.09 & 0.07 & 0.16 \\
\hline
\end{tabular}

The influence of the different concentrations of the plant additives on P. ostreatus grown on banana leaves/sawdust (BLSD) composite is presented on Table 2.Control experiments produced mushrooms with larger pileus size $\left(36.08 \mathrm{~cm}^{2}\right)$ when compared with results from treated substrates. However, BLSD treated to 15 $\mathrm{g} M$. oleifera performed significantly better than other levels of treatments producing mushrooms with pileus size as large as $26.74 \mathrm{~cm}^{2}$. The highest mean fresh weight $(20.64 \mathrm{~g})$ was obtained when the substrate was treated to $10 \mathrm{~g} \mathrm{~J}$. insularis. Mushrooms with longer stipes $(4.90 \mathrm{~cm}$ ) were produced by the control samples. This was followed by samples treated to $15 \mathrm{~g} \mathrm{M}$. oleifera leaf powder and then the $10 \mathrm{~g} \mathrm{~J}$. insularis treated samples. Units amended with all levels of $D$. sammatii did not support the growth of the test mushroom on BLSD. Assessment of stipe girth revealed that amendment with $10 \mathrm{~g} \mathrm{~J}$. insularis exhibited the best results followed by the $15 \mathrm{~g} M$. oleifera treatment which was, however, comparable with the control experiment but better than what was obtained in samples treated to other additives. 
Yield Performances of Pleurotus Ostreatus on Different Growth Substrates as Influence by Some

Table 2: Effect of different concentration levels of additives on the growth parameters of Pleurotus ostreatus grown banana leaves/sawdust substrates

\begin{tabular}{|c|c|c|c|c|c|c|}
\hline \multirow[t]{2}{*}{ Treatments } & \multicolumn{6}{|c|}{$\begin{array}{l}\text { Area of pileus }\left(\mathrm{cm}^{2}\right) / \text { Fresh and dry wt. }(\mathrm{g}) / \text { Length and girth of stipe }(\mathrm{cm}) / \mathrm{No} \text {. of fruit bodies } \\
\text { (count) }\end{array}$} \\
\hline & $\begin{array}{l}\text { Area of } \\
\text { Pileus }\end{array}$ & Fresh wt. & Dry wt. & Length of stipe & $\begin{array}{l}\text { Girth of } \\
\text { stipe }\end{array}$ & No of fruit bodies \\
\hline Control & 36.08 & 17.76 & 2.39 & 4.10 & 3.31 & 6.00 \\
\hline $5 \mathrm{~g}$ Diplaziumsammatii & 0.00 & 0.00 & 0.00 & 0.00 & 0.00 & 0.00 \\
\hline $10 \mathrm{~g}$ Diplaziumsammatii & 0.00 & 0.00 & 0.00 & 0.00 & 0.00 & 0.00 \\
\hline $15 \mathrm{~g}$ Diplaziumsammatii & 0.00 & 0.00 & 0.00 & 0.00 & 0.00 & 0.00 \\
\hline $5 \mathrm{~g}$ Justiciainsularis & 8.15 & 6.13 & 0.62 & 1.40 & 1.22 & 2.00 \\
\hline $10 \mathrm{gJusticiainsularis}$ & 25.09 & 20.64 & 1.66 & 4.40 & 3.44 & 8.00 \\
\hline 15 gJusticiainsularis & 11.93 & 8.53 & 0.65 & 1.78 & 1.44 & 2.00 \\
\hline 5 gMoringaoleifera & 15.91 & 7.61 & 0.76 & 2.06 & 1.72 & 1.00 \\
\hline $10 \mathrm{gMoringaoleifera}$ & 11.74 & 8.53 & 0.82 & 1.22 & 1.11 & 5.00 \\
\hline $15 \mathrm{~g}$ Moringaoleifera & 26.74 & 19.49 & 1.65 & 4.80 & 3.33 & 7.00 \\
\hline LSD & 0.66 & 0.40 & 0.03 & 0.09 & 0.07 & 0.16 \\
\hline
\end{tabular}

\section{Discussion}

All BL/SD substrates supplemented with D. sammatii leaf powder failed to support growth of the test mushroom throughout the course of the experiment. This growth inhibitory effect may be as a result of the synergistic effect of some anti-nutritional components in sawdust and in D. sammatii. Evaluation of the effects of the three plants additives on the growth parameters of Pleurotus ostreatus cultivated on two substrates; BL and $\mathrm{BL} / \mathrm{SD}$ showed that there were significant variations $(\mathrm{P} \leq 0.05)$ in the various growth parameters tested. The influence of the different concentrations of the plant additives on P. ostreatus grown on banana leaves/sawdust (BLSD) composite is presented on Table 2.However, BL substrates amended with $J$. insularis leaf powder recorded better results when compared with samples with other plant additives especially at $5 \mathrm{~g}$ and $10 \mathrm{~g}$ concentration levels.

Assessment of the influence of substrates and additives on the pileus area, fresh and dry weights of the mushroom revealed that these parameters recorded higher growth values in BL substrates treated with $M$. oleifera leaf powder, especially, at lower concentrations and declined with increasing concentrations of the additive (Table 1). The largest pileus size $\left(42.48 \mathrm{~cm}^{2}\right)$ was observed in mushroom produced on BL supplemented with $M$. oleifera leaf powder at $5 \mathrm{~g}$ concentration. This indicates that the maximum effective growth support concentration of $M$. oleifera is $5 \mathrm{~g}$ and that beyond this concentration level, the amount of antinutritional factors in the plant powder may have assumed inhibitory levels, hence the growth decline observed in concentrations above $5 \mathrm{~g}$ [18, 20. 19]. Markson et al., (2012), reported similar values for fresh weight when PKC (palm kernel cake) and GC (groundnut cake) + PKC were added to sawdust for the cultivation of $P$. ostreatus. However, in BLSD, increment in the concentration of M. oleifera concomitantly increased growth, especially, the fresh weight, the stipe length and girth as well as the number of fruit bodies of the test mushroom. This disparity in the growth performance exhibited by M. oleifera leaf powder in these two substrate types may be deduced from the contribution from sawdust in the composite substrate. It appears that there are some substances in sawdust thatcomplement the growth support potentials of the additive and mask the growth inhibiting effects of $M$. oleifera at elevated concentrations. It also appears that at concentrations beyond $10 \mathrm{~g}, M$. oleifera does not add to the growth of some mushroom organs like area of pileus and dry weight. Mshandete and Kivaisi (2013) reported that the number of fruit bodies increased as the percentage of cow dung was increased.

In BL/SD composite, $J$. insularis leaf powder was best at $10 \mathrm{~g}$ concentration $\left(25.09 \mathrm{~cm}^{2}\right)$. Though the control experiment yielded better mushroom growth, but the yield produced by the addition of J. insularis leaf powder was comparable. The performance of $J$. insularis is likely a function of the mushroom to effectively convert the high level of protein contained in the leaf of this plant to body structures. The growth of stipe (length and girth) was greatly influenced by the addition of $5 \mathrm{~g}$ and $15 \mathrm{~g} \mathrm{M}$. oleifera to BL and BLSD substrates respectively. This result is a pointer to the fact that the level of concentration of a certain additive and the interactions of certain additives and the substrates actually influenced the growth pattern of mushrooms. There is an observable alignment between additives and substrates, and the additive concentrations as they impact on growth pattern of the test mushroom. This trend could be exploited for growth of selective organs of interest. Similar observation was made by Mshandete (2013) in same mushroom. He reported increase in stipe length with amendment of growth substrates with $30 \%$ cow dung.

\section{Conclusion}

From the findings of this study, it is evident that treatment of BL substrates to $5 \mathrm{~g} M$. oleifera leaf powder and BL/SD with $10 \mathrm{~g} \mathrm{~J}$. insularis and $15 \mathrm{~g} \mathrm{M}$. oleifera gave maximum yield of the Pleurotus ostreatus. These vegetables have high potential for utilization as additives or supplements for growing of Pleurotus 
ostreatus, especially, when using BL as substrates. Specific observations made during this project indicate that the growth of certain organs of mushrooms can be selectively promoted or suppressed with the right combinations of substrates and additives at certain concentration levels. This trend of research should be exploited as it may reveal certain facts about the metabolic pathways that lead to this and possible discovery of more concerning molecular signaling involving fungal cell organelles. This may give insights into ways where some key phenotypic characters could be effectively modified using nutrient therapy.

\section{References}

[1]. M. Kuo Pleurotus ostreatus: The oyster mushroom. http://www.mushroomexpert.com/pleurotus_ostreatus.html 2005. Retrieved $15 / 02 / 2012$

[2]. G. Eger, G. Eden, and E. Wissig Pleurotus ostreatus-breeding potential of a new cultivated mushroom.Theoretical and applied Genetics, 47, 1976, 155-163.

[3]. M. J. Obodai, Cleland-Okire and A. K. Vowotor, Comparative study on growth and yield of Pleurotusostreatus on different lignocellulosic bye-products.Journal Industrial Microbiology Biotechnology30, 2005, 146-149.

[4]. M. Sadler, Nutritional Properties of Edible Fungi.Nutrition bulletin, 28, 2003,305-308.

[5]. A. A. Markson, B.E. Madunagu,U.D. Akpan and E. I. Eshiet, Growth influence of some additives on mycelia growth and fruit body development of Pleurotus ostreatus (Jacq.Et. Fr) Kummer. Journal of Biology, Agriculture and Healthcare 2(3), 2012, 59-67.

[6]. J. A. Buswell, C. Yi Jin, S.T.Chang, J. F Peberdy, S. Y Fu, andH. S. Yu, Lignocellulolytic Enzyme Profiles of edible mushroom fungi. World Journal of Microbiology and Biotechnology.12, 1996, 537-542.

[7]. S. Soniya, K. P. Y.Ram, andP. P Chandra, Growth and Yield of Oyster mushroom (Pleurotus ostreatus) on different substrates. Journal of New Biological Reports, 2(1), 2013, 3-8

[8]. S. R. Mondal, M. J. Rehana, M. S. Noman and S. K. Adhikary, Comparative study on growth and yield performance of oyster mushroom (Pleurotus florida) on different substrates. Journal of Bangladesh Agricultural University. 8(2), 2010, 213-220.

[9]. K. J. Kimenju, G. O. M. Odero, E. N. Mutitu, P. M. Wachira, R. D. Narla, and W. M. Muiru, Suitability of locally available substrates for oyster mushroom (Pleurotus ostreatus) cultivation in Kenya. Asian Journal of Plant science, 8 (7), 2009, 510-514

[10]. A. S. Ajonina, and L. E. Tatah, Growth performance and yield of Oyster mushroom (Pleurotus ostreatus) on Different substrates composition in Beua South west Cameroon. Science Journal of Biochemistry.2012, Article ID sjbch-139, 6 Pages, 2012.doi: $10.7237 / \mathrm{sjbch} / 139$

[11]. K. M. Ananbeh, and A. M. Al-Momany, Production of Oyster mushroom (Pleurotus ostreatus) on oil cake agro waste. Dirasat, 32 (1), 2005, 64-70

[12]. K. M. Ananbeh, and A. M. Al-Momany, Production of Oyster mushroom (Pleurotus ostreatus) on tomato tuff agro waste. Dirasat, 35 (3), 2008, 133-138

[13]. A. M. Mshandete, and A. K. Kivaisi, Cultivation of oyster mushroom (Pleurotus HK-37) on solid sisal waste fractions supplemented with cow dung manure. Journal of Biology and Life Science. 2(1), 2013, 273-286.

[14]. P. Reganathan, A. Eswaran and R. S. W. Wijeratnan, Effects of various additives on the bed substrates on the sporophore production by Pleurotus flabellatus (Berk and Br) sacc. Mysore Journal of Agricultural Science 42(1), 2008, $132-134$.

[15]. J. O. Fasidi, Substrate source and preparation for mushroom cultivation. A paper presented at the workshop on cultivation of edible mushroom, Department of Botany, University of Ibadan, Nigeria. $20^{\text {th }}-22^{\text {nd }}$ November, 2006.

[16]. P. Prakash, B. A. Aashish, J. K. Neil, and Sivasubramman, Effect of humic acid on Pleurotus ostreatus mushroom cultivation and analysis of their nutrient contents.Research Journal agriculture and Biological Sciences 6(6) 2010, 1067-1070

[17]. J. Frimpong-Manso, M. Obodai, M. Dzomeku, and M. M. Apertorgbor, Influence of rice husk on biological efficiency and nutrient content of Pleurotus ostreatus (Jacq. Ex. Fr) Kummer. International Food Research Journal,18, 2011,249-254.

[18]. A. O.Ogbe, and P. J. Affiku, Proximate study, mineral and anti-nutrient composition of Moringa oleifera leaves harvested from Lafia, Nigeria: potential benefits in poultry nutrition and health. Journal of microbiology, Biotechnology and Food science.1 (3), 2012, 296-308

[19]. M. O. Agba, Substrates amendment with some vegetables for the cultivation of Pleurotus ostreatus. M.Sc. thesis, University of Calabar, Nigeria, 2015

[20]. P. M. Aja, U. A. Ibiam, A. J. Uraku, O. U. Orji, C. E. Offor, and B. U. Nwali,. Comparative proximate and mineral composition of Moringa oleifera leaf and seed. Global Advanced Research Journal of Agriculture, 2 (5), 2013, 137-141.

[21]. N. V. Osabor, E. G. Egbung, andM. U. Ntuk, Chemical evaluation of the leaves of Diplaziumsammatii "Nyamaidim". Research Journal of Agriculture and Biological Sciences, 6(6), 2010, 1074-1077. 